\begin{tabular}{|c|c|c|}
\hline $20<$ & Our Nature & $\begin{array}{l}\text { ISSN: 1991-2951 (Print) } \\
\text { ISSN: 2091-2781 (Online) }\end{array}$ \\
\hline 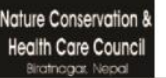 & Journal homepage: http://nepjol.info/index.php/ON & (c) (1) (8) \\
\hline
\end{tabular}

\title{
Comparative leaf morphology and anatomy on ten taxa of Calycanthaceae Lindl. (Laurales)
}

\author{
Niroj Paudel* and Kweon Heo \\ Department of Applied Plant Science, Kangwon National University, Chuncheon 24341, Republic of \\ Korea \\ *E-mail:nirojjirauna@gmail.com
}

\begin{abstract}
The comparative leaf morphology and anatomy of ten species of family Calycanthaceae have been studied. Leaf anatomy is very comparable to each other in cell shape and their arrangement. Collected leaves were preserved in FAA and alcohol series were applied for LM and SEM. The layer of epidermis is two in Idiospermum and one in rest of other genera. The structure of vascular bundle is V-shape in Sinocalycanthus and Calycanthus whereas U-shape in Idiospermum and Chimonanthus. The density of trichome is higher in Calycanthus than other genera. The presence of trichome, stomata, epidermal layer, density of trichome and stomata, and leaf surface are represented the distinction among the genera. The adaxial surface of Idiospermum and Sinocalycanthus are smooth whereas of Calycanthus and Chimonanthus are rough. The crystals are present in Calycanthus, Sinocalycanthus and Chimonanthus whereas absent in Idiospermum. The shape of the vascular bundle, density of trichome, epidermal layer, and crystals play important role in the phylogenetic relationship of Calycanthaceae.
\end{abstract}

Key words: Adaxial and abaxial surface, Calycanthus, Stomata, Trichomes, Vascular bundle

DOI: https://doi.org/10.3126/on.v19.i1.41212

Manuscript details: Received: 15.01.2021 / Accepted: 03.08.2021

Citation: Paudel, N and K. Heo 2021. Comparative leaf morphology and anatomy on ten taxa of Calycanthaceae Lindl. (Laurales). Our Nature 19(1): 1-9. DOI: https://doi.org/10.3126/on.v19.i1.41212

Copyright: (C) Paudel and Heo 2021. Creative Commons Attribution - Non Commercial 4.0 International License.

\section{Introduction}

The Calycanthaceae are a small family of flowering plant under the order Laurales, inhabited in tropical and warm temperate regions and contains only ten known species with the debate in four or three genera (Cheng and Chang, 1964; Nicely, 1965; Blake, 1972; Renner, 1999, 2005; Zhou et al., 2006; Paudel and Heo, 2018a, b, c; 2020a, b). Calycanthaceae are deciduous except Chimonanthus nitens, which is an evergreen species (Nicely, 1965). The family consists of famous ornamental small tree, used as medicine and foods, and are mainly distributed in Australia, North America, and China (Xu et al., 2018). In the APG IV system, Calycanthaceae placed in the order Laurales (Chase et al., 2016). Calycanthaceae are unique among Laurales due to differ from the ovule number and placentation in other Laurales, and the seed of Idiospermum is one of the largest embryo known in angiosperms (Blake, 1972). In Calycanthaceae, carpels have two ovules per carpel with collateral placentation, positioned one on top and other at an anthesis (Blake, 1972; Endress and Igersheim, 1997). The evolutionary trend of stomata in the three genera was recognized as the guard cell at polar region from having no T-shaped thickening ( $\mathrm{Li}$ and $\mathrm{Li}, 2000$ ). The developmental studies are on the gynoecium in Calycanthus (Erbar and Leins, 1983; Van Heel, 1984). There is no information about the gynoecium development of Idiospermum despite its extremely large seeds (Blake, 1972). Within the Calycanthaceae, authentic gynoecium features are unique to Idiospermum which the presence of only one 


\section{Paudel and Heo / Our Nature | December 2021 | 19 (1): 1-9}

carpel (Worboys and Jackes, 2005). The morphology of Idiospermum australiense is distinctively different from that of the rest of the Calycanthaceae, especially in gynoecium morphology (Staedler et al., 2009). Bennett (1950) found no evidence that the cortical system is a modification of lateral traces of a trilacunar alternatively, multilacunar nodal. The apparent lateral traces of trilacunar or multilacunar nodal are in case some dicot families. Eames (1961) believed that it was an additional independent system, which had four vas ular bundles of The leaves of ten species of Calycanthaceae were collected and fixed with FAA (Table 1). The serial section of 5-6 $\mu \mathrm{m}$ thickness using disposable knives stuck onto glass slides and dried on electrical slide warmer for $24 \mathrm{hrs}$. The dried slides stained with $0.1 \%$ Toluidine blue $\mathrm{O}$ for $60-90 \mathrm{sec}$, rinsed with running water, and dried again on the electrical warmer for more than $6 \mathrm{hrs}$ to remove water. The stained slides were mounted with Entellan (Merck Co., Germany). The slides were observed under unilacunar structure of the primary cylinder. Bennett (1950) also indicated that transverse connections between the cortical strands, which are presented in the nodal region of Calycanthus, less well developed than Chimonanthus. Black (1972) noted the detail vegetative structure for Idiospermum. Furthermore, Wilson (1976) found that nodal anatomy and pattern of leaf trace are very similar between the Calycanthacae and Idiospermaceae.

\section{Materials and Methods}

Olympus BX50 light microscope (Olympus Co., Japan). Photographs were taken with digital camera system attached to the microscope, and the multiple image alignments were done using Photoshop CS6. For scanning electron microscopy, the pre-treatment was applied. The preserved leaf samples were passed through the ethyl-alcohol series, then immersed in $100 \%$ ethanol after that dried from the critical point dryer (CPD). SEM images were carried out from KBSI, Chuncheon at EHT=3.0kV.

Table 1. Collection information of ten species of Calycanthaceae used in the present study.

\begin{tabular}{|c|c|}
\hline Taxa & Collection information \\
\hline alycanthus occidentalis HooK. \& Arn. & $\begin{array}{l}\text { Korea. Cultivated at Kangwon National University, K. Heo \& N. } \\
\text { Paudel s.n. } 2016 \text { (KWNU) }\end{array}$ \\
\hline Chimonanthus fragrans (Loisel.) Lind. & Korea. Cultivated in Chollipo Arboretum, K. Heo s.n. 2009 (KWNU) \\
\hline Chimonanthus luteus (G.Don) Biel. & Korea. Cultivated in Chollipo Arboretum, K. Heo s.n. 2009 (KWNU) \\
\hline Chimonanthus nitens (Oliv.) Rehder & Korea. Cultivated in Chollipo Arboretum, K. Heo s.n. 2009 (KWNU) \\
\hline Chimonanthus praecox (L.) Link & $\begin{array}{l}\text { Korea. Cultivated at Kangwon National University, K. Heo \& N. } \\
\text { Paudel s.n. } 2016 \text { (KWNU) }\end{array}$ \\
\hline Chimonanthus salicifolius S.Y. Hu & Korea. Cultivated in Chollipo Arboretum, K. Heo s.n. 2009 (KWNL \\
\hline $\begin{array}{l}\text { Chimonanthus yunnanensis (W.W.Sm.) } \\
\mathrm{Hu}\end{array}$ & Korea. Cultivated in Chollipo Arboretum, K. Heo s.n. 2009 (KWNU) \\
\hline ensis M.C. Liu. & Korea \\
\hline Idiospermum australiense S.T. Blake & $\begin{array}{l}\text { Australia. Central Coast, Cultivated in Royal Botanical Garden, } \\
\text { Sydney, R.G. Coveny s.n. } 1994 \text { (KWNU) }\end{array}$ \\
\hline $\begin{array}{l}\text { inocalycanthus chinensis W.C.Cheng \& } \\
\text {.Y.Chang }\end{array}$ & $\begin{array}{l}\text { Korea. Cultivated at Kangwon National University, K. Heo \& N. } \\
\text { Paudel s.n. } 2016 \text { (KWNU) }\end{array}$ \\
\hline
\end{tabular}

\section{Results and discussion}

Trichome: Trichomes were frequently occurred on the mid rib and secondary vein (Fig. 1). They were unicellular and non-glandular (Figs. 1A-G). The density of trichome was lower in adaxial than that of the abaxial surface in Calycanthus (Fig. 1A). Trichomes were originated from the base and arranged horizontally in Chimonanthus nitens (Fig. 1D). They were rarely found in adaxial surface in C. salicifolius (Fig. 1F). In addition, the density and frequency of trichomes were different among the genera (Table 2). In Chimonanthus zhenjingenensis, Idiospermum australiense and

\section{Adaxial surface}

Sinocalycanthus chinensis, trichomes were not observed on adaxial surface (Figs. 1H-J).

\section{Abaxial surface}

Trichome: Trichomes were densely occurred on the dorsal and ventral veins (Fig. 2). The density of trichome was lower in Sinocalycanthus than that of Calycanthus (Fig. 2J). In Calycanthus occidentalis, trichomes were densely found on both abaxial and adaxial surfaces (Fig. 2A). In comparison, the density of the trichomes was lower on adaxial than that on abaxial surface. Trichome was found rarely 
in adaxial surface in Chimonanthus salicifolius (Fig. 2F).
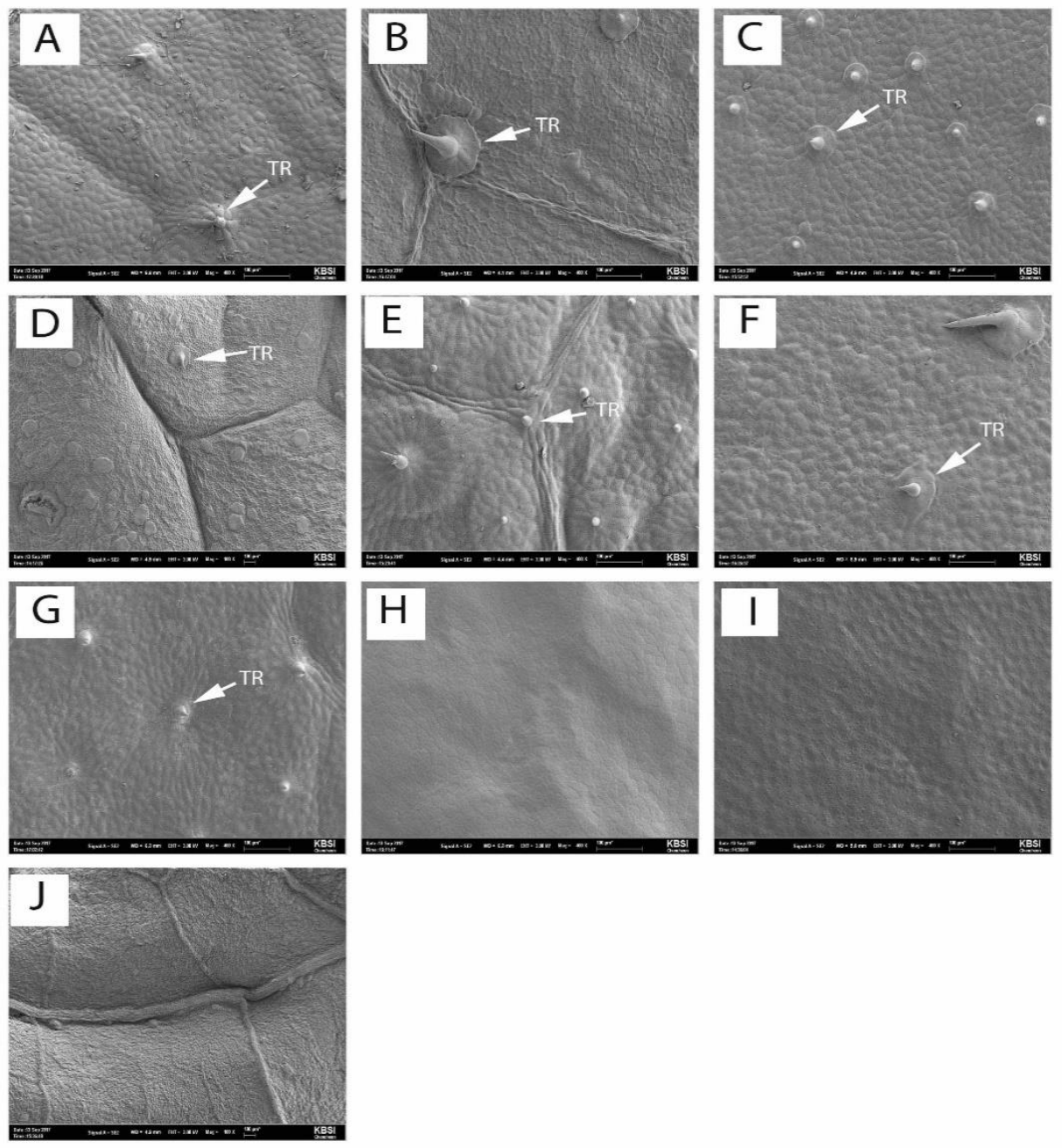

Figure 1. Trichome development on the adaxial leaf surface of Calycanthaceae: A. Calycanthus occidentalis, B. Chimonanthus fragrans, C. C. luteus, D. C. nitens, E. C. praecox, F. C. salicifolius, G. C. yunnanensis. H. C. zhejiangensis, I. Idiospermum australiense, J. Sinocalycanthus chinensis. (TR= trichome)

Table 2. Leaf morphology and anatomy of ten species of Calycanthaceae.

\begin{tabular}{|c|c|c|c|c|c|c|}
\hline \multirow[b]{2}{*}{ Taxa } & \multicolumn{2}{|c|}{ Trichome } & \multirow{2}{*}{$\begin{array}{c}\text { Shape of } \\
\text { epidermal cell } \\
\text { in } \mathrm{CS}\end{array}$} & \multirow[b]{2}{*}{$\begin{array}{l}\text { Epidermal } \\
\text { cell surface }\end{array}$} & \multirow{2}{*}{$\begin{array}{c}\text { Shape of } \\
\text { vascular } \\
\text { bundle }\end{array}$} & \multirow[b]{2}{*}{ Crystal } \\
\hline & $\begin{array}{c}\text { Adaxial } \\
\text { surface }\end{array}$ & $\begin{array}{c}\text { Abaxial } \\
\text { surface }\end{array}$ & & & & \\
\hline Calycanthus occidentalis & $\begin{array}{c}\text { Present, } \\
\text { rarely }\end{array}$ & $\begin{array}{l}\text { Present, } \\
\text { densely }\end{array}$ & Barrel shape & Irregular & V-shape & Absent \\
\hline Chimonanthus fragrans & $\begin{array}{l}\text { Present, } \\
\text { rarely }\end{array}$ & $\begin{array}{l}\text { Present, } \\
\text { moderately }\end{array}$ & Barrel shape & $\begin{array}{l}\text { Haphazardly } \\
\text { irregular }\end{array}$ & U-shape & Present \\
\hline Chimonanthus luteus & $\begin{array}{l}\text { Present, } \\
\text { densely }\end{array}$ & $\begin{array}{l}\text { Present, } \\
\text { densely }\end{array}$ & Rectangular & Hexagonal & U-shape & Present \\
\hline Chimonanthus nitens & $\begin{array}{l}\text { Present, } \\
\text { densely }\end{array}$ & $\begin{array}{l}\text { Present, } \\
\text { densely }\end{array}$ & $\begin{array}{c}\text { Barrel shape, } \\
\text { rectangular }\end{array}$ & $\begin{array}{l}\text { Irregular, } \\
\text { rough }\end{array}$ & U-shape & Absent \\
\hline Chimonanthu praecox & $\begin{array}{l}\text { Present, } \\
\text { densely }\end{array}$ & $\begin{array}{l}\text { Present, } \\
\text { densely }\end{array}$ & Rectangular & Hexagonal & U-shape & Present \\
\hline Chimonanthus salicifolius & $\begin{array}{l}\text { Present, } \\
\text { densely }\end{array}$ & $\begin{array}{l}\text { Present, } \\
\text { moderately }\end{array}$ & Rectangular & $\begin{array}{l}\text { Irregular, } \\
\text { rough }\end{array}$ & U-shape & Present \\
\hline
\end{tabular}


Paudel and Heo / Our Nature | December 2021 | 19 (1): 1-9

\begin{tabular}{|c|c|c|c|c|c|c|}
\hline Chimonanthus yunnanensis & Present, & Present, & Rectangular & Irregular, & U-shape & Absent \\
\hline Chimonanthus zhejiangenensis & Absent & $\begin{array}{l}\text { Present, } \\
\text { moderately }\end{array}$ & $\begin{array}{c}\text { Barrel shape, } \\
\text { rounded }\end{array}$ & $\begin{array}{l}\text { Irregular, } \\
\text { smooth }\end{array}$ & U-shape & Absent \\
\hline Idiospermum australiense & Absent & $\begin{array}{c}\text { Present, } \\
\text { rarely }\end{array}$ & $\begin{array}{l}\text { Barrel shape, } \\
\text { rectangular }\end{array}$ & $\begin{array}{l}\text { Irregular, } \\
\text { rough }\end{array}$ & U-shape & Absent \\
\hline Sinocalycanthus chinensis & Absent & $\begin{array}{l}\text { Present, } \\
\text { moderately }\end{array}$ & Rectangular & Irregular & V-shape & Present \\
\hline
\end{tabular}

Stomata structure: The surface view of stomata showed the key differences among the four genera. In all genera, stomata were distributed in abaxial surface (Fig. 2). The deep seat and protect filament like special band cell were the different characters in Calycanthus occidentalis (Fig. 3A). The stomata are generally elongated shape in Chimonanthus species but rounded in Calycanthus and Sinocalycanthus chinensis (Fig. 2). In all species, stomata were paracytic (Figs. 2A-J). The density of stomata was the lowest in Idiospermum (Fig. 2J)

\section{Leaf anatomy}

Epidermis: The shape of epidermal cells was rectangular. The upper epidermis cell was thicker than lower epidermis. In all genera, the continuity of the epidermis was broken by the presence of stomata in abaxial side (Fig. 3). The shape and size of epidermal cells were varied in all genera. Adaxial and abaxial epidermis were barrel-shaped cells in Calycanthus occidentalis, Chimonanthus fragrans, $C$. zhejiangensis, and Idiospermum australiense (Figs. 3A-B, 3H-I). There were welldeveloped hypodermal layers in Idiospermum (Fig. 3I).

Mesophyll: The palisade was more developed on the adaxial side with radially elongated cells. The number of palisade layer was clearly shown in Calycanthaceae (Fig. 3). All species have single layered of palisade (Figs. 3A-J). Well-developed hypodermis is the distinguished feature of Idiospermum australiense (Figs. 3I, L). The spongy parenchyma organized with loosely arranged polygonal cells containing many chloroplasts in all genera. The spongy parenchyma is loosely arranged and occupied more space than the palisade. Crystal was observed in mesophyll in Chimonanthus fragrans, C. luteus, C. praecox, C. salicifolius and Sinocalycanthus chinensis (Figs. 3B-C, 3E-F, 3J$\mathrm{K})$.
Mesophyll: The palisade was more developed on the adaxial side with radially elongated cells. The number of palisade layer was clearly shown in Calycanthaceae (Fig. 3). All species have single layered of palisade (Figs. 3A-J). Well-developed hypodermis is the distinguished feature of Idiospermum australiense (Figs. 3I, L). The spongy parenchyma organized with loosely arranged polygonal cells containing many chloroplasts in all genera. The spongy parenchyma is loosely arranged and occupied more space than the palisade. Crystal was observed in mesophyll in Chimonanthus fragrans, C. luteus, C. praecox, C. salicifolius and Sinocalycanthus chinensis (Figs. 3B-C, 3E-F, 3J$\mathrm{K})$.

Vascular bundle: The vascular bundle was Vshape in Calycanthus occidentalis and Sinocalycanthus chinensis (Figs. 4A, 4J), whereas it was U-shaped in Chimonanthus and Idiospermum (Figs. 4B-I). The vascular bundles were scattered in spongy parenchyma (Fig. 4). C. zhejiangensis was highly differentiated from the other species and detected the closest relationship with Chimonanthus salicifolius, which possibly supported that $C$. zhejiangensis was a distinct species rather than the $C$. nitens. Besides, $C$. praecox was much more closely related with $C$. campanulatus than the other species moreover extensive genetic differentiation existed among $C$. praecox (Zhou et al., 2006). In results, the leaf anatomy is different for the genera of Calycanthaceae. Many researchers focused on their description of the plant for molecular phylogeny from the molecular data (Renner 1999; Qui et al., 2005). Cuticle morphology and cross section of leaf are strongly represented similarities and dissimilarities characters for phylogeny of Calycanthaceae. The floral structure and floral architecture in Calycanthaceae were studied (Staedler et al., 2007, 2009). The presence of welldeveloped vascular bundle is in Chimonanthus 


\section{Paudel and Heo / Our Nature | December 2021 | 19 (1): 1-9}

praecox, C. nitens, C. fragrans, C. salicifolius, C. zhejiangensis, C. yunnanensis, and C. luteus.

A vascular bundle appears as the continuous ring of primary xylem and primary phloem. In our results, primary xylem and primary phloem for Sinocalycanthus chinensis, Calycanthus occidentalis and Chimonanthus fragrans, C. nitens, C. salicifolius, C. yunnanensis, C. luteus, C. zhejiangenensis, $C$. praecox were advanced and arranged in compact formed. The bundle sheath and trichome are the characteristics of Calycanthus occidentalis. Chimonanthus zhejiangensis is unique to the other without a trichome. Stomata size and frequency, the epidermal cell structure, the trichome type and distribution pattern are the diagnostic treatment for the taxa (Oak et al., 2018). The cuticle ornamentation was striate, undulate striate, favolate, granular with cavities and the stomata are the paracytic type (Ruohui et al., 1993).
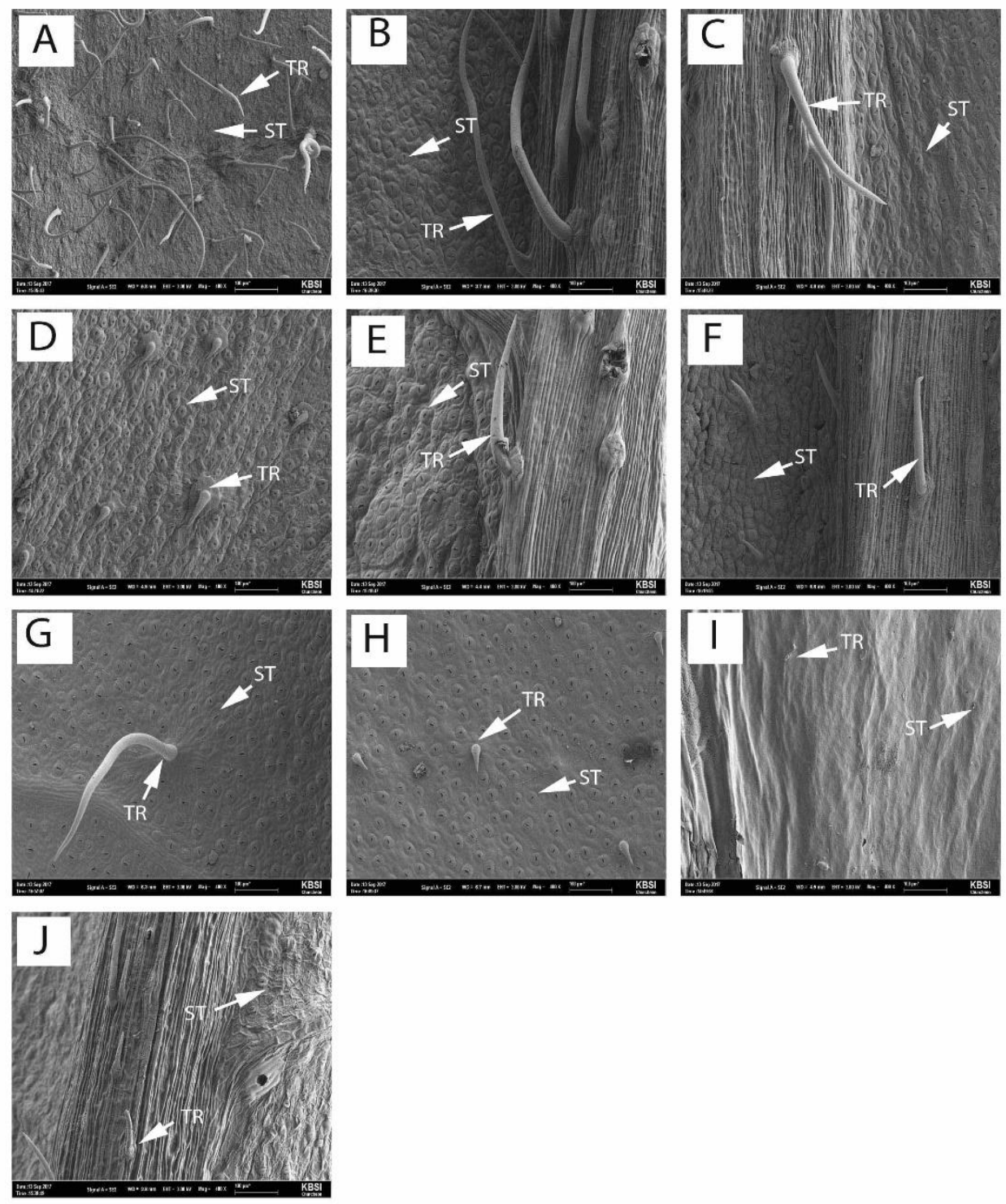

Figure 2. Trichome and stomata on the abaxial surface of Calycanthaceae: A. Calycanthus occidentalis, B. Chimonanthus fragrans. C. C. luteus. D. C. nitens, E. C. praecox, F. C. salicifolius, G. C. yunnanensis, H. C. zhejiangensis, I. Idiospermum australiense, J. Sinocalycanthus chinensis. $(\mathrm{TR}=$ trichome, ST= stomata) 

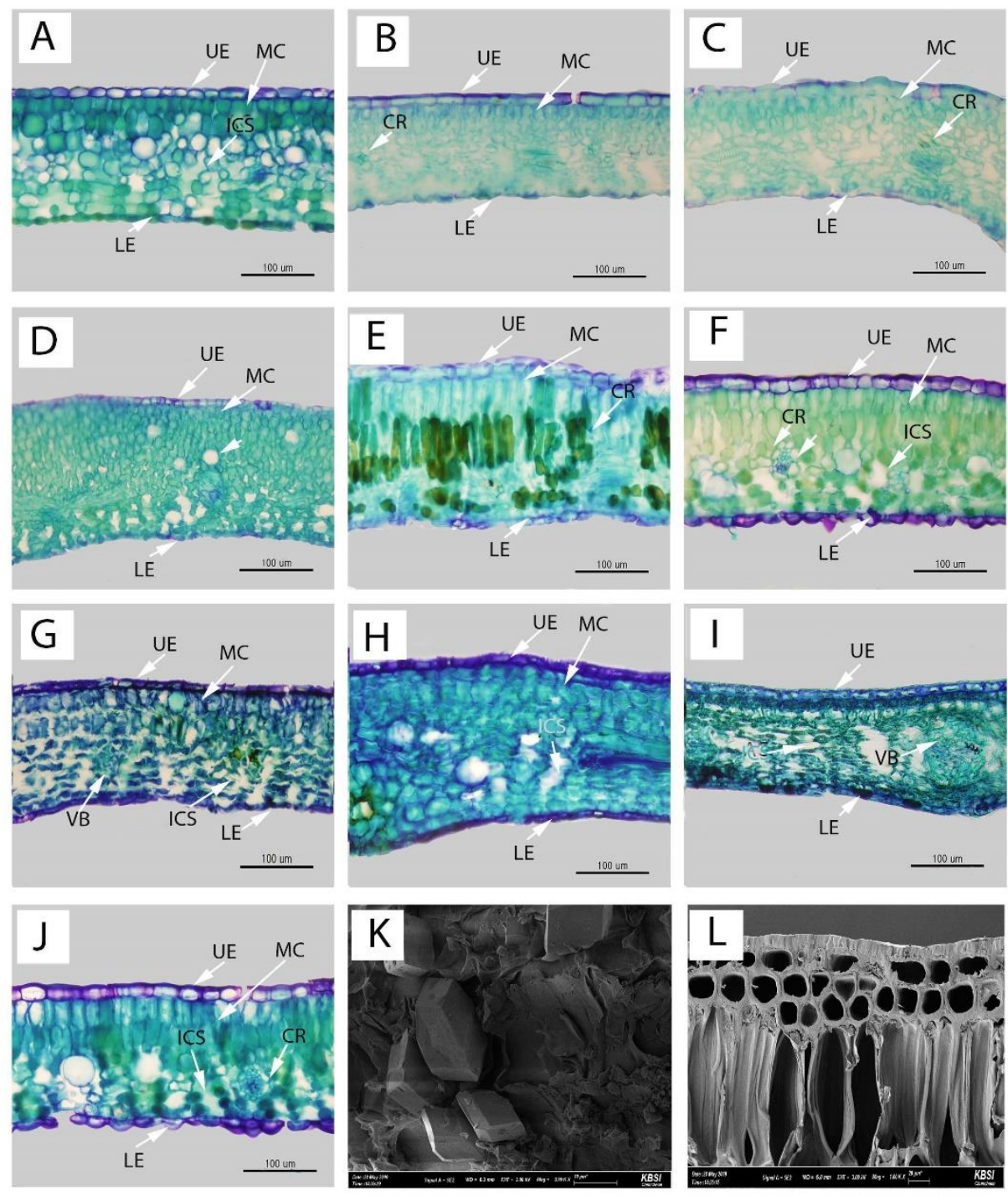

Figure 3. Cross section of leaf blade of Calycanthaceae: A. Calycanthus occidentalis, B. Chimonanthus fragrans, C. C. luteus, D. C. nitens, E \& K. C. praecox, F. C. salicifolius, G. C. yunnanensis, H. C. zhejiangensis, I \& L. Idiospermum australiense, J. Sinocalycanthus chinensis. (UE= upper epidermis, LE= lower epidermis, $\mathrm{MC}=$ mesophyll cell, $\mathrm{ICS}=$ inter-cellular space, $\mathrm{CR}=$ crystal, $\mathrm{HP}=$ hypodermis)

Present results are supporting for the paracytic stomata and granular trichome. Stomata density, chloroplast density in palisade and spongy parenchyma were indistinct which are the characteristic features (Leroy et al., 2008). Those characters are similar in case of Calycanthaceae. The present results noted that those characters are represented in the Calycanthaceae. The type of the trichome is unicellular with variable length (Nicely, 1965). The stomata are only on the lower surface as rubiaceous accompanied with either side of more subsidiary cells parallel to the long axis pore of the guard cells (Metcalfe and Chalk, 1950). In all genera, stomata are observed as paracytic. The leaf of the Calycanthaceae has great taxonomic value for the anatomical and morphological point of view. The results are for the density of trichome, stomata character between adaxial and abaxial surfaces, epidermal surface shape. Additionally, structure of vascular bundle, mesophyll tissue layer, spongy mesophyll, and bundle sheath extension are the characters for the phylogeny of Calycanthaceae. 

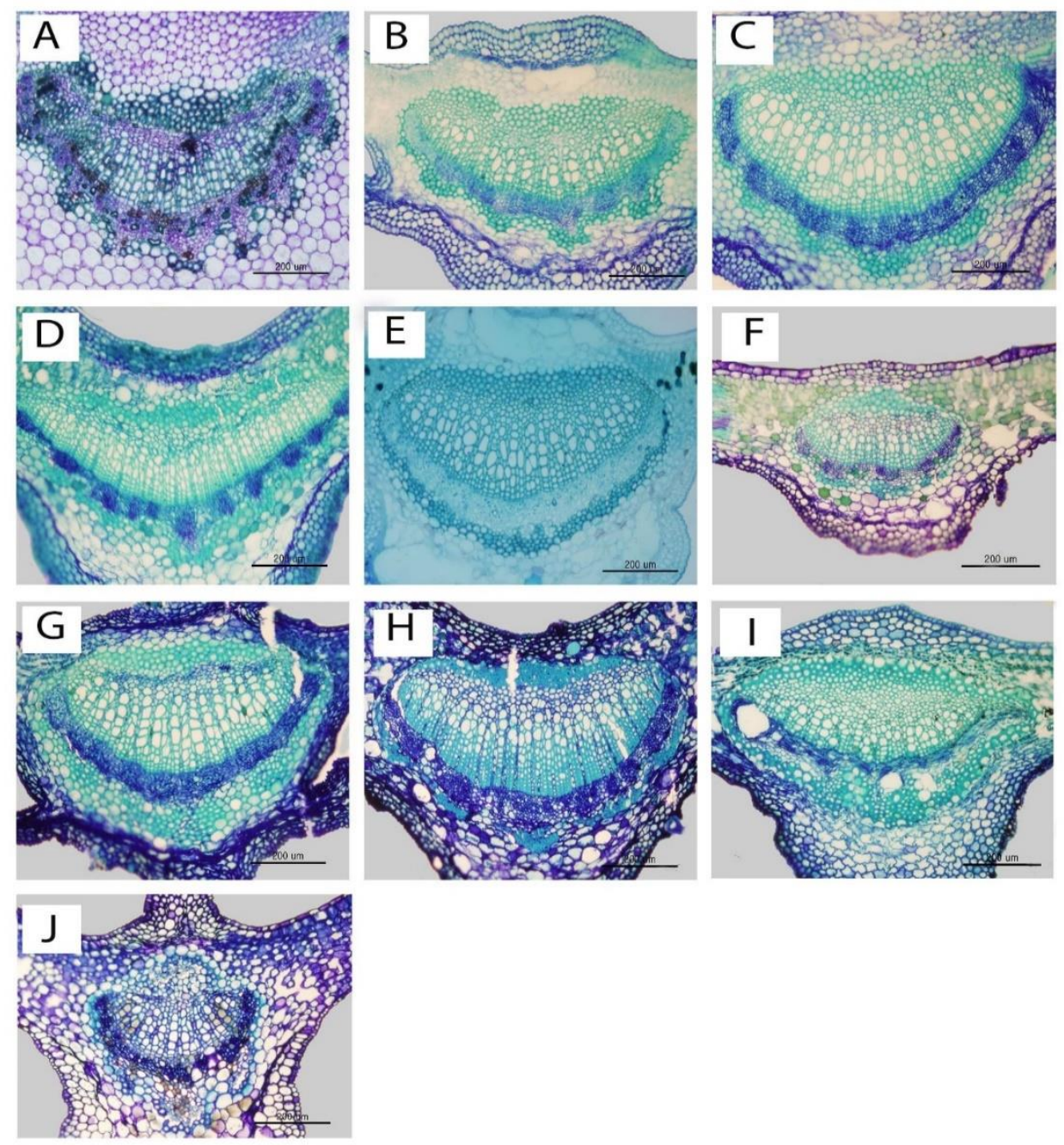

Figure 4. Shape of vascular bundle in mid rib of Calycanthaceae: A. Calycanthus occidentalis, B. Chimonanthus fragrans, C. C. luteus, D. C. nitens, E. C. praecox, F. C. salicifolius, G. C. yunnanensis, H. C. zhejiangensis, I. Idiospermum australiense, J. Sinocalycanthus chinensis

The result shows that the density of trichome in abaxial surface is high in Calycanthus occidentalis in compare to the Chimonanthus praecox, $C$. nitens, $C$. fragrans, $C$. salicifolius, $C$. zhejingenensis, $C$. yunnanensis, and C. luteus. On the other hand, Idiospermum australiense trichome is not presented in the abaxial surface.

The stomata density in Sinocalycanthus is similar as in Calycanthus but, in Chimonanthus, it is comparatively slightly lower. Also, noted that the upper epidermal layer is smooth in Idiospermum australiense whereas rough in Sinocalycanthus and Chimonanthus except $C$. zhejiangensis. In anatomical features, result shows there was well-developed hypodermis in
Idiospermum. The morphological and anatomical characters of the leaves treated for the proper placement of the genus. Sinocalycanthus and Calycanthus are similar as the following characteristics; epidermis cell is paranchymatous, elongated subsidiary cells; but in Idiospermum and Chimonanthus epidermal cells are irregular with paranchymatous, and V-shaped vascular bundle. In addition, Chimonanthus was rounded stomata with U-shaped vascular bundle in mid rib, which is the common character of all species. In Idiospermum, subsidiary cell is not distinguished. The characteristic features of the leaf morphology and anatomy are important for phylogeny of Calycanthaceae. 


\section{Our Nature | December 2021 | 19 (1): 1-9}

\section{Conclusion}

The presented comparative leaf anatomy and morphology of small family Calycanthacae is very comparable to each other in cell shape and their arrangement. The vascular bundle is noted $\mathrm{U}$ and $\mathrm{V}$ shaped. Furthermore, the distinct characteristic is between the trichome, stomata, epidermal layer, density of trichome and stomata.

\section{Acknowledgements}

Authors are thankful to the Department of Applied Plant Science, Kangwon National University (KNU) for laboratory facilities.

\section{References}

Bennett, H.D. 1950. Some aspects of the seed and seedling anatomy of Calycanthus floridus $L$. State University of Iowa, USA. (Ph.D. Thesis)

Blake, S.T. 1972. Idiospermum (Idiospermaceae), a new genus and family for Calycanthus australiensis. Contribution from the Queensland Herb 12: 1-37.

Chase, M.W., M.J.M. Christenhusz, M.F. Fay, J.W. Byng, W.S. Judd, D.E. Soltis, D.J. Mabberley, A.N. Sennikov, P.S. Soltis and P.F. Stevens 2016. An update of the Angiosperm Phylogeny Group classification for the orders and families of flowering plants: APG IV. Botanical Journal of the Linnean Society 181(1): 1-20. https://doi.org/10.1111/boj.12385

Cheng, W.C. and S.Y. Chang 1964. Genus novum Calycanthacearum chinaeorientalis Acta Phytotaxonomica Sinica 9: 137-138.

Eames, A.J. 1961. Morphology of the Angiosperms (1st ed.). McGrew-Hill, London.

Endress, P.K. and A. Igersheim 1997. Gynoecium diversity and systematics of the Laurales. Botanical Journal of the Linnean Society 125(2): 93-168. https://doi.org/10.1006/boj1.1997.0113

Erbar, C. and P. Leins 1983. Zur Sequenz von Blutenorganen bei einigen Magnoliiden (On the sequence of floral organs in some Magnoliidae). Botanische Jahrbucher fur Systematik 103: 433-449.

Leroy, C., A. Jauneau, A. Quilichini, A. Dejean and J. Orivel 2008. Comparison between the anatomical and morphological structure of leaf blades and foliar domatia in the ant-plant
The adaxial surface is also notable characteristic for the taxonomy point of view. The crystals are the unique remarkable characteristic for the taxonomy of Calycanthacae. All characters presented here on anatomy and morphology of leaf are remarkable for the phylogenetic relationship of the Calycanthaceae.

Hirtella physophora (Chrysobalanaceae). Annals of Botany 101(4): 501-507. https://doi.org/10.1093/aob/mcm323

Li, Y. and B. Li 2000. Origin, evolution and distribution of the Calycanthaceae. Guangxi Zhiwu 20(4): 295-300.

Metcalfe, C.R. and L. Chalk 1950. Anatomy of the Dicotyledons. Clarendon Press, Oxford; Univ. Toronto Press, Toronto. 1500p.

Nicely, K.A. 1965. A monographic study of the Calycanthaceae. Castanea 30: 38-81.

Oak, M-K., J-H. Song and S-P. Hong 2018. The taxonomic implication of leaf micromorphological characteristics in the genus Aruncus (Rosaceae). Korean Journal of Plant Taxonomy 48(2): 143-152. https://doi.org/10.11110/kjpt.2018.48.2.143

Paudel, N. and K. Heo 2018a. Comparative stem anatomy of four taxa of Calycanthaceae Lindl. European Journal of Biological Research 8(1): 34-41. http://doi.org/10.528/zendo.1199578

Paudel, N. and K. Heo 2018b. Pericarp, seed coat anatomy and seed morphology of Calycanthaceae. International Journal of Plant Biology 9(1): 19-28. https://doi.org//10.4081/pb.2018.7525

Paudel, N. and K. Heo 2018c. Additional characters for taxonomic treatment on Chimonanthus praecox (L.) Link (Calycanthaceae). Flora-Morphology Distribution Functional Ecology of Plants 249: $\quad 150-155$. https://doi.org/10.1016/j.flora.2018.11.004

Paudel, N. and K. Heo 2020a. Comparative pollen morphology of Calycanthaceae for their taxonomic implication. European Journal of Biological Research 10(2): 74-80. http:dx.doi.org/10.5281/zenodo.3763335

Paudel, N. and K. Heo 2020b. Cladistics analysis of Calycanthaceae on the basis of morphological and anatomical characters. European Journal of Biological Research 


\section{Our Nature | December 2021 | 19 (1): 1-9}

$10(3):$

182-187.

http:/dx.doi.org/10.5281/zenodo.3908965

Qui, Y.-L., O. Dombrovaska, J. Lee, L. Li, B.A. Whitlock, F. Bernasconi-Quadroni, J.S. Rest, C.C. Davis, T. Borsch, K.W. Hilu, S.S. Renner, D.E. Soltis, P.S. Soltis, M.J. Zanis, J.J. Cannone, R.R. Gutell, M. Powell, V. Savolaninen, L.W. Chatrou and M.W. Chase 2005. Phylogenetic analyses of basal angiosperms based on nine plastid, mitochondrial, and nuclear genes. International Journal of Plant Sciences 166(5): $815-842$. https://dx.doi.org/10.1086/431800

Renner, S.S. 1999. Circumscription and phylogeny of the Laurales: evidence from molecular and morphological data. American Journal of Botany 86(9): 1301-1315.

Renner, S.S. 2005. Variation in diversity among Laurales, Early Cretaceous to present. Skrifter/Kongelike danske videnskabernes Selskab. 55: 441-458. PMID: 10487818

Ruohui, Z., H. Jianqin and L. Hong'e 1993. Leaf epidermis characters of Calycanthaceae and their taxonomic significance. Journal of Zhejiang Forestry College 4: 368-377.

Staedler, Y.M., P.H. Weston and P. K. Endress 2009. Comparative gynoecium structure and development in Calycanthaceae (Laurales). International Journal of Plant Sciences $170(1)$ : 21-41. https://doi.org/10.1086/593045

Bardgett, R.D., A.C. Jones, D.L. Jones, S.J. Kemmitt and P.J. Hobbs 2001. Soil microbial community patterns related to the history and intensity of grazing in sub montane ecosystems. Soil Biology and Biochemistry 33: 1653-1664. http://dx.doi.org/10.1016/S0 0380717(01)00086-4

Aandahl, A.R. 1981. Soils of the Great Plains: Land Use, Crops and Grasses. Universityof Nebraska Press, Nebraska.
Staedler, Y.M., P.H. Weston and P.K. Endress 2007. Floral phyllotaxis and floral architecture in Calycanthaceae (Laurales). International Journal of Plant Sciences 168(3): 285-306. https://doi.org/10.1086/510417

van Heel, W.A. 1984. Variation in the development of ascidiform carpels, an S.E.M. - Investigation. Blumea 29: 443-452.

Wilson, C.L. 1976. Floral anatomy of Idiospermum australiense (Idiospermaceae). American Journal of Botany 63(7): 987-996. https://doi.org/10.1002/j.15372197.1976.tb13180.x

Worboys, S.J. and B.R. Jackes 2005. Pollination processes in Idiospermum australiense (Calycanthaceae), an arborescent basal angiosperm of Australia's tropical rain forests. Plant Systematics and Evolution 251: 107-117. https://doi.org/10.1007/s00606004-0226-z.

Xu, J.B., J.J. Pan and K.L. Cheng 2018. Research advance on chemical constituents for Calycanthaceae plants and their pharmacological activities. Zhong Zhong Zazi. Chinese Material Medica 43: 19571968.

Zhou, S., S.S. Renner and J. Wen 2006. Molecular phylogeny and intra- and intercontinental biogeography of Calycanthaceae. Molecular Phylogenetics and Evolution 39(1): 1-15. 